\title{
Phenotyping Almond Orchards for Architectural Traits Influenced by Rootstock Choice
}

\author{
Álvaro Montesinos ${ }^{1,2}\left(\mathbb{D}\right.$, Grant Thorp ${ }^{3}{ }^{(D}$, Jérôme Grimplet ${ }^{1,2}$ and María José Rubio-Cabetas ${ }^{1,2, *}$ \\ 1 Centro de Investigación y Tecnología Agroalimentaria de Aragón (CITA), Unidad de Hortofruticultura, \\ Gobierno de Aragón, Avda. Montañana 930, 50059 Zaragoza, Spain; amontesinos@cita-aragon.es (Á.M.); \\ jgrimplet@cita-aragon.es (J.G.) \\ 2 Instituto Agroalimentario de Aragón-IA2 (CITA-Universidad de Zaragoza), Calle Miguel Servet 177, \\ 50013 Zaragoza, Spain \\ 3 Plant \& Food Research Australia Pty Ltd., 7 Bevan St, Albert Park, Melbourne, VIC 3206, Australia; \\ grant.thorp@plantandfood.com.au \\ * Correspondence: mjrubioc@cita-aragon.es
}

Citation: Montesinos, Á.; Thorp, G.; Grimplet, J.; Rubio-Cabetas, M.J. Phenotyping Almond Orchards for Architectural Traits Influenced by Rootstock Choice. Horticulturae 2021, 7, 159. https://doi.org/10.3390/ horticulturae7070159

Academic Editor:

Alessandra Francini

Received: 4 June 2021

Accepted: 17 June 2021

Published: 22 June 2021

Corrected: 20 April 2022

Publisher's Note: MDPI stays neutral with regard to jurisdictional claims in published maps and institutional affiliations.

Copyright: (c) 2021 by the authors. Licensee MDPI, Basel, Switzerland. This article is an open access article distributed under the terms and conditions of the Creative Commons Attribution (CC BY) license (https:// creativecommons.org/licenses/by/ $4.0 /)$.

\begin{abstract}
The cropping potential of almond (Prunus amygdalus (L.) Batsch, syn P. dulcis (Mill.)) cultivars is determined by their adaptation to edaphoclimatic and environmental conditions. The effects of scion-rootstock interactions on vigor have a decisive impact on this cropping success. Intensively planted orchards with smaller less vigorous trees present several potential benefits for increasing orchard profitability. While several studies have examined rootstock effects on tree vigor, it is less clear how rootstocks influence more specific aspects of tree architecture. The objective of this current study was to identify which architectural traits of commercially important scion cultivars are influenced by rootstock and which of these traits can be useful as descriptors of rootstock performance in breeding evaluations. To do this, 6 almond cultivars of commercial significance were grafted onto 5 hybrid rootstocks, resulting in 30 combinations that were measured after their second year of growth. We observed that rootstock choice mainly influenced branch production, but the effects were not consistent across the different scion-rootstock combinations evaluated. This lack of consistency in response highlights the importance of the unique interaction between each rootstock and its respective scion genotype.
\end{abstract}

Keywords: Prunus dulcis; branching; tree habit; rootstock-scion interaction; hybrid rootstock; vigor

\section{Introduction}

Since its development, reported around 1800 BCE, grafting has been a crucial part of the propagation process for tree and vine crops [1]. As well as conferring traits of agronomic interest to trees in the orchard, the use of grafting and clonal rootstocks has facilitated the independent selection of scion and rootstock traits, thus improving breeding techniques. Rootstocks can be selected for relevant root system traits, including conferring resistance to pathogens such as root knot nematodes, endowing tolerance of alkaline and calcareous soils and promoting higher yields in non-irrigated soils [2]. Rootstocks can also influence scion phenotype such as fruit quality, yield, flowering time and tree vigor [3-7].

Nowadays, clonal rootstocks are utilized in numerous fruit and nut species of economic significance [7]. Their usage is widespread in almond (Prunus amygdalus (L.) Batsch, syn $P$. dulcis (Mill.)) orchards, and varieties are generally graft-compatible with both almond and peach (P. persica (L.) Batsch) rootstocks and their interspecific hybrids [2,8]. In the last decade, several new dwarfing rootstocks have been developed, conferring low and medium vigor to establish new more intensive and sustainable cropping systems.

Due to their global significance as a major tree fruit crop, rootstock effects on scion vigor have mostly been studied in apple (Malus $\times$ domestica). In these studies, rootstock effects have mainly been described in generic vigor-related parameters such as scion height, 
trunk diameter, shoot length and frequency of branching $[9,10]$. Apple dwarfing rootstocks can also stimulate flowering in young trees, which indirectly affects shoot production and shoot vigor [11]. Young apple trees on dwarfing rootstocks form more floral buds and thus more axillary bourse shoots compared with the more vigorous terminal shoots produced from purely vegetative buds. Rootstock involvement in more specific aspects of tree architecture is less clear, and there is often a lack of consistency in responses among different cultivars, which highlights the importance of scion-rootstock interactions [10,12]. While previous studies with almond have described rootstock effects on vigor in generic terms $[13,14]$, knowledge of rootstock influence on more specific architectural traits and their wider influence over almond tree architecture is still limited.

First introduced by Halle et al. [15], architectural analysis of trees provided a way to analyze the dynamics of plant development that is applicable to any species. The architectural tree models developed from this work are based on four major features: (i) temporal growth pattern, (ii) branching pattern, (iii) morphological differentiation of axes and (iv) sexual differentiation of meristems [16]. A total of 23 different architectural models were found in nature from all possible combinations of these features [15].

Temporal growth patterns predominantly have two features: rhythmic vs. continuous growth and determinate vs. indeterminate growth [17]. Continuous growth is a rare phenomenon and is not observed in Rosaceae species, whose shoots alternate periods of active growth and rest [18]. Determinate growth refers to the abortion or transformation of the terminal bud into a specialized structure [15]. If the apical meristem maintains indefinitely its function, then growth is indeterminate. Branching is a key aspect in defining tree structure. An axillary meristem may develop into a shoot at the same time as the extension of the parent axis, without a period of rest or dormancy, to form a sylleptic shoot [15]. Otherwise, the axillary meristem remains inactive and only develops into a shoot after a period of rest or dormancy, forming a proleptic shoot. Rhythmic (zonal) branching is constituted by groups of branched nodes followed by a succession of unbranched nodes. Diffuse branching is when shoots are disposed uniformly along the main axis [19]. Determinate and indeterminate growth patterns can lead to two different branching patterns, sympodial and monopodial, respectively [17]. Sympodial growth is when continued growth of the primary axis occurs via successive growth of axillary buds in subterminal positions, while monopodial growth occurs via continued extension of a single terminal meristem or bud [15]. The sum of all these features constitutes the architectural tree model.

Markovian models have been used to build general models for describing tree structure [20]. These methods analyze tree architecture as a succession of zones with a different proportion of node types whose arrangement is defined by transition probabilities, using branches as the study subject [16,21-23]. This approach has been applied to almond under different circumstances [24-26]. Although these models are useful for describing and visualizing repetitive patterns in tree architecture and branching formation, they are difficult to incorporate into genomic analyses, such as genome-wide association studies (GWAS). Therefore, accurate and objective measurements are needed. There have been few advancements in the analysis of these kinds of quantitative traits focused on their heritability or on the influence of the environment [27-29]. Recently, high-throughput phenotyping technologies such as T-LiDAR have been used in apple orchards to identify different architectural groups [30]. However, these methods fall short in describing the physiology and control processes determining tree shape and architecture or in distinguishing the nuanced changes that exist between different rootstock/scion combinations. Furthermore, there are considerable difficulties in measuring a substantial number of architectural traits in enough individuals in large trees modified by pruning. It is easier to record these traits of interest on young, unpruned trees.

The objective of the research presented here was to identify which architectural traits of the scion cultivar are influenced by rootstock genotype and which of these traits can be used as reliable descriptors of rootstock performance in breeding evaluations. We 
did this by characterizing the genotype-specific effects of a selection of rootstocks on the architecture of a range of important scion cultivars.

\section{Materials and Methods}

\subsection{Plant Material and Growth Conditions}

For the experiment, 6 almond cultivars of agronomic interest were grafted onto 5 different commercial rootstocks, resulting in a total of 30 different combinations. The scion cultivars selected were 'Isabelona' (syn. Belona), 'Soleta', 'Guara', 'Vialfas', 'Diamar' (syn. Mardia) and 'Lauranne'. All are important commercial cultivars in Spain. The rootstocks were selected to represent a range of vigor responses in the grafted scion: 'GN8', 'Densipac' (Rootpac $\left.{ }^{\circledR} 20\right)$, 'Nanopac' (Rootpac $\left.{ }^{\circledR} 40\right)$, 'Replantpac' $\left(\operatorname{Rootpac}^{\circledR} \mathrm{R}\right)$ and 'Garnem' (GN15). All were hybrid rootstocks from different origins. 'Garnem' and 'GN-8' are both almond $\times$ peach (P. amygdalus (L.) Batsch, syn P. dulcis (Mill.). $\times$ P. persica (L.) Batsch) hybrid rootstocks, while the 3 others came from the commercial Rootpac ${ }^{\circledR}$ series including Rootpac ${ }^{\circledR} 40$ (P. amygdalus (L.) Batsch, syn P. dulcis (Mill.). $\times$ P. persica (L.) Batsch), Rootpac ${ }^{\circledR} 20\left(\right.$ P. cerasifera $\times$ P. besseyi) and Rootpac ${ }^{\circledR} \mathrm{R}($ P. cerasifera $\times$ P. amygdalus (L.) Batsch, syn P. dulcis (Mill.)). Grafted plants were supplied by the Agromillora Iberia S.L. nursery in 2018 (Barcelona, Spain). Trees were planted during October 2018 at the Centro de Investigación y Tecnología Agroalimentaria de Aragón (CITA) experimental orchard El Vedado Bajo el Horno (Zuera, Zaragoza, 41 $51^{\prime} 46.5^{\prime \prime} \mathrm{N} 0^{\circ} 39^{\prime} 09.2^{\prime \prime} \mathrm{W}$ ). Trees were planted as a single stem and supported by a wooden stake. Trees were then left without pruning so that they could express their natural growth habit unaltered. Conventional orchard practices were used for weed control and drip irrigation. Soil type was calcareous with $\mathrm{pH}$ around $7-8$.

\subsection{Architectural Traits}

Data collection was carried out during winter 2020 after two growing seasons from a total of 90 trees with 3 trees per scion-rootstock combination (Figure 1). In total, 24 parameters were considered as possible descriptors of tree architecture, divided into four categories: tree vigor, branching quantity and vigor, branching distribution and branching angle (Table 1). In this context, the primary growth axis of the tree was referred to as the trunk with axillary shoots forming directly on the trunk during the first season's growth. A branch was regarded as a second-order structure comprising multiple axillary shoots present during the second season's growth. The tree vigor category included five parameters. Total trunk length (TL) and number of internodes $\left(\mathrm{Nb} \_\mathrm{IN}\right)$ were determined from the graft union to the apex of the tree, and average internode length (IN_L) was calculated from those two measures. Trunk diameter was measured at both $20 \mathrm{~mm}$ above the graft union (d_Base) and $20 \mathrm{~mm}$ (d_Top) below the apex of the tree. Seven parameters were included in the branch quantity and vigor category. The total number of branches formed directly on the trunk $\left(\mathrm{Nb} \_\mathrm{B}\right)$ was recorded as was the number of axillary shoots formed on these branches (B_NbAS). Three categories of shoot length were used to describe branching frequency along the trunk; these categories were short $(<100 \mathrm{~mm})$, medium $(100-200 \mathrm{~mm})$ and long $(>200 \mathrm{~mm})$, denoted as $\mathrm{Nb} \_\mathrm{sB}, \mathrm{Nb} \_\mathrm{mB}$ and $\mathrm{Nb} \_\mathrm{lB}$, respectively. The ratio of branches by trunk length (BbyL) and trunk internodes (BbyIN) were calculated. Vigor was also recorded as branch diameter measured both at the base (B_dBase) and at the apex (B_dTop) of each branch along the trunk. The branch distribution category included the internode in which each branch was positioned along the trunk. Also determined from this value was the mean distribution of branches along the trunk (Dist_B), as well as the percentage of shoots in each third of the trunk from the basal to middle and distal sections (Dist_Down, Dist_Med and Dist_Up, respectively). Branching angle was recorded for branches formed directly on the trunk as the angle relative to the trunk at the base of the branch and at the branch tip. Three categories were used to describe branching angle: upright $\left(<45^{\circ}\right)$, semi-open $\left(45-65^{\circ}\right)$ and open $\left(>65^{\circ}\right)$, resulting in the following according to their base angle (Base_U, Base_SO and Base_O) and tip angle (Top_U, Top_SO and Top_O). 
In total, 17 variables were established directly from measured data, while 7 variables were calculated combining some of the initial measurements.

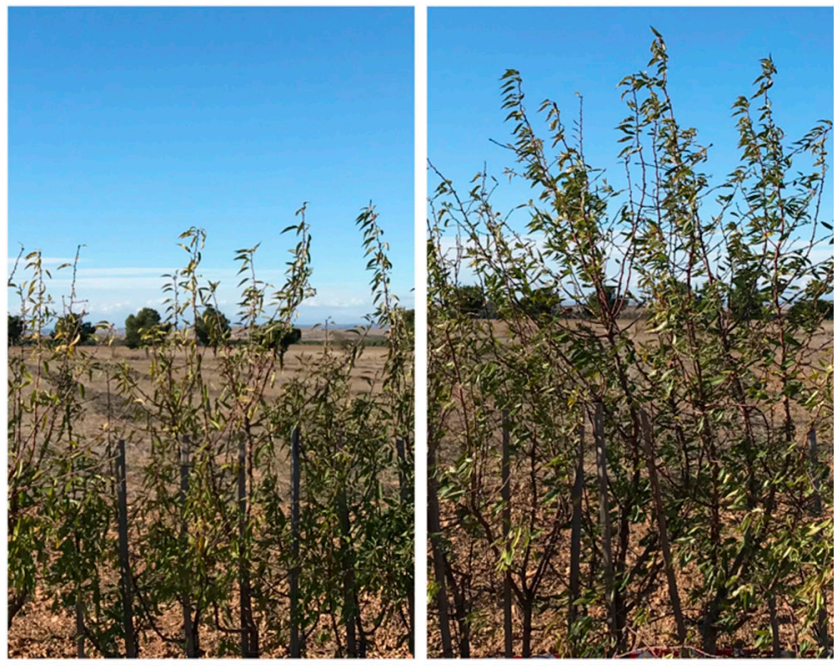

(a)

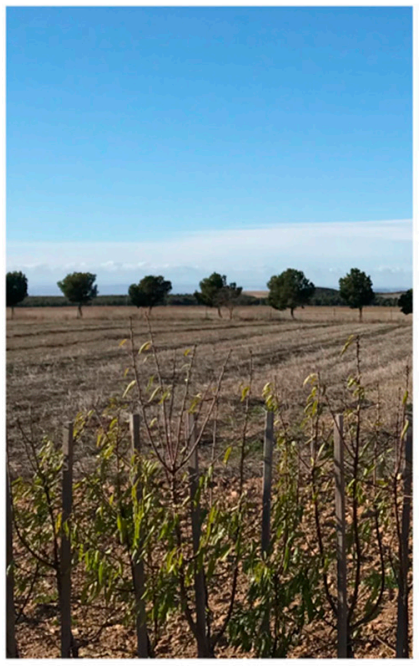

(b)

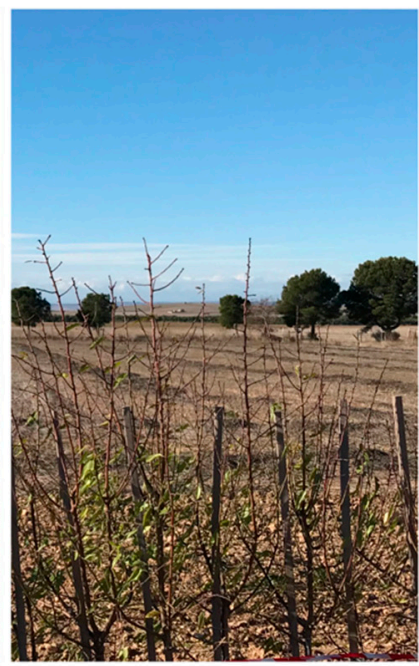

Figure 1. Scion-rootstock combinations of 2-year-old almond trees show low and high vigor responses: (a) 'Guara' and (b) 'Diamar' grafted onto 'GN-8' (left) and 'Garnem' (right) rootstocks, respectively.

Table 1. Parameters used to quantify aspects of almond tree architecture and the corresponding formula if parameters were calculated from other traits. Data were measured on the primary growth axis (trunk) or axillary branches of 2-year-old almond trees for 30 scion-rootstock combinations.

\begin{tabular}{|c|c|c|c|c|}
\hline Type & Parameter & Formula & Trunk & Branches \\
\hline \multirow{5}{*}{ Vigor } & Number of internodes & & $\mathrm{Nb} \_\mathrm{IN}$ & \\
\hline & Length (mm) & & Length & \\
\hline & Average lenght of internodes (mm) & Length/Nb_IN & IN_L & \\
\hline & Base diameter (mm) & & d_Base & B_dBase \\
\hline & Apex diameter (mm) & & d_Top & B_dTop \\
\hline \multirow{6}{*}{$\begin{array}{l}\text { Branch } \\
\text { quantity }\end{array}$} & Number of branches & & $\mathrm{Nb} \_\mathrm{B}$ & B_NbAS \\
\hline & Ratio of branches by trunk internodes & $\mathrm{Nb} \_\mathrm{B} / \mathrm{Nb} \_\mathrm{IN}$ & BbyIN & \\
\hline & Ratio of branches by trunk length & $\mathrm{Nb} \_\mathrm{B} /$ Length & BbyL & \\
\hline & Number of short branches $(<100 \mathrm{~mm})$ & & $\mathrm{Nb} \_s B$ & \\
\hline & Number of medium branches (100-200 mm) & & $\mathrm{Nb} \_\mathrm{mB}$ & \\
\hline & Number of long branches (>200 mm) & & $\mathrm{Nb} \_\mathrm{lB}$ & \\
\hline \multirow{4}{*}{$\begin{array}{c}\text { Branch } \\
\text { distribution }\end{array}$} & Mean distribution of branches trought the trunk & $\mathrm{SUM}(\mathrm{IN}) / \mathrm{Nb} \_\mathrm{IN}$ & Dist_B & \\
\hline & Percentage of branches in the 1st third of the trunk & NbDown/Nb_B & Dist_Down & \\
\hline & Percentage of branches in the 2 nd third of the trunk & $\mathrm{NbMed} / \mathrm{Nb} \_\mathrm{B}$ & Dist_Med & \\
\hline & Percentage of branches in the 3rd third of the trunk & NbTop/Nb_B & Dist_Up & \\
\hline \multirow{6}{*}{$\begin{array}{c}\text { Branching } \\
\text { habit }\end{array}$} & Number of upright branches measured at the base $\left(<45^{\circ}\right)$ & & Base_U & \\
\hline & Number of semiopen branches measured at the base $\left(45-65^{\circ}\right)$ & & Base_SO & \\
\hline & Number of open branches measured at the base $\left(>65^{\circ}\right)$ & & Base_O & \\
\hline & Number of upright branches measured at the apex $\left(<45^{\circ}\right)$ & & Top_U & \\
\hline & Number of semiopen branches measured at the apex $\left(45-65^{\circ}\right)$ & & Top_SO & \\
\hline & Number of open branches measured at the apex $\left(>65^{\circ}\right)$ & & Top_O & \\
\hline
\end{tabular}




\subsection{Statistical Analysis}

All statistical analyses were carried out in the R platform (https:/ / cran.r-project.org/, accessed on 11 June 2021). To identify which parameters were most influenced by rootstock genotype, a two-way ANOVA test was performed using the $\mathrm{R}$ stats package in order to establish which of the 24 measured parameters described in Table 1 were influenced by the rootstock genotype. Although the two-way ANOVA test allowed us to observe the influence on the variability of both the rootstock and the cultivar separately, we limited our focus to the effects of their interaction. Since all data were collected from the scion, the interaction of the two independent variables, rootstock and cultivar, described the extent of rootstock influence in aerial architectural traits. Parameters were selected as being influenced by rootstock choice when the $p$-value was lower than 0.1. Pearson's correlation coefficients were computed using the Hmisc R package (https: / /CRAN.R-project.org/package=Hmisc, accessed on 20 December 2020). Parameters correlating with an $r$ value higher than +0.7 or lower than -0.7 were considered redundant, and a single parameter was conserved for analyses. Principal component analysis (PCA) was carried out using the R stats package with default parameters. The rootstock effect on each individual cultivar was evaluated using an ANOVA test to find significant differences. These were assessed with the Tukey's test $(p<0.05)$ using the agricolae R package (https:/ /CRAN.R-project.org/package=agricolae, accessed on 24 January 2021).

\section{Results}

\subsection{Rootstock Influence in Trait Variability}

Out of the 24 starting parameters described in Table 1, 15 of these had a $p$-value lower than 0.10 , and of these, 11 had a $p$-value lower than 0.05 (Table 2). Four scion vigor variables were identified as affected by the rootstock choice: Nb_IN, Length, IN_L and d_Top. However, a scion-rootstock interaction was observed for the diameter at the base of the scion (d_Base), which is equivalent to the trunk cross sectional area (TCSA), even though it could be expected that a more vigorous rootstock should have an effect on this trait. No influence was observed for the vigor parameters measured on the branches, such as B_dBase and B_dTop. All traits representing branch quantity were identified as influenced by the rootstock, suggesting that branching may be strongly affected by rootstock selection. Branch distribution parameters were predominately affected by rootstock genotype, with the exception of Dist_Med. Rootstock did not appear to affect branching angle, since only Top_SO might be characterized as being influenced by the rootstock. All 15 parameters with a $p$-value lower than 0.1 were considered as possibly influenced by the rootstock and were used in further analyses.

Table 2. Analysis of the effects of 30 almond scion-rootstock combinations on variability in architectural traits as affected by scion and rootstock genotype and the interaction between the two. Refer to Table 1 for abbreviations.

\begin{tabular}{ccccc}
\hline Trait & Cultivar & Rootstock & $\begin{array}{c}\text { Cultivar } \times \text { Rootstock } \\
\text { Interaction }\end{array}$ \\
\hline \multirow{6}{*}{ Vigor } & Nb_IN & $2.21 \times 10^{-6}$ & 0.726 & $\mathbf{4 . 2 1} \times 10^{-7}$ \\
& Length & 0.00263 & 0.23671 & $\mathbf{4 . 0 1} \times 10^{-5}$ \\
& IN_L & $3.87 \times 10^{-10}$ & 0.000153 & $\mathbf{0 . 0 8 0 9 1 9}$ \\
& d_Base & $4.06 \times 10^{-10}$ & $7.32 \times 10^{-6}$ & 0.168 \\
& d_Top & $8.29 \times 10^{-5}$ & 0.28228 & $\mathbf{0 . 0 0 6 9 6}$ \\
& B_dBase & $8.74 \times 10^{-8}$ & 0.00189 & 0.23873 \\
& B_dTop & 0.0986 & 0.0686 & 0.1342 \\
\hline
\end{tabular}


Table 2. Cont.

\begin{tabular}{|c|c|c|c|c|}
\hline & Trait & Cultivar & Rootstock & $\begin{array}{c}\text { Cultivar } \times \text { Rootstock } \\
\text { Interaction }\end{array}$ \\
\hline \multirow{7}{*}{$\begin{array}{l}\text { Branch } \\
\text { quantity }\end{array}$} & $\mathrm{Nb} \_\mathrm{B}$ & 0.00037 & $1.14 \times 10^{-12}$ & 0.01043 \\
\hline & BbyIN & 0.000152 & $1.20 \times 10^{-7}$ & 0.001294 \\
\hline & BbyL & 0.001262 & $8.53 \times 10^{-7}$ & 0.000649 \\
\hline & B_NbAS & $7.93 \times 10^{-9}$ & 0.00547 & 0.05479 \\
\hline & Nb_sB & $3.47 \times 10^{-5}$ & 0.00036 & 0.05135 \\
\hline & $\mathrm{Nb} \_\mathrm{mB}$ & 0.00208 & $8.33 \times 10^{-7}$ & 0.01555 \\
\hline & Nb_lB & 0.00634 & $1.65 \times 10^{-9}$ & 0.00814 \\
\hline \multirow{4}{*}{$\begin{array}{c}\text { Branch } \\
\text { distribution }\end{array}$} & Dist_B & 0.00256 & 0.08757 & 0.00303 \\
\hline & Dist_Down & 0.249 & 0.7719 & 0.0288 \\
\hline & Dist_Med & 0.4682 & 0.0288 & 0.2746 \\
\hline & Dist_Up & 0.0127 & 0.0116 & 0.0169 \\
\hline \multirow{6}{*}{$\begin{array}{c}\text { Branching } \\
\text { habit }\end{array}$} & Base_U & 0.7449 & 0.0541 & 0.9252 \\
\hline & Base_SO & 0.182 & 0.0156 & 0.6591 \\
\hline & Base_O & 0.0643 & $2.96 \times 10^{-5}$ & 0.3477 \\
\hline & Top_U & 0.00336 & $7.06 \times 10^{-7}$ & 0.11616 \\
\hline & Top_SO & 0.2424 & 0.3178 & 0.0845 \\
\hline & Top_O & 0.0247 & $7.55 \times 10^{-7}$ & 0.6563 \\
\hline
\end{tabular}
bold.

\subsection{Identification of Relevant Parameters and Interaction between Different Categories}

Correlation values between parameters were analyzed in a two-part approach. Firstly, variables belonging to the same category with a correlation value higher than +0.7 or lower than -0.7 were considered redundant, and a unique representative parameter was selected. Secondly, correlation values above +0.32 or below -0.32 between traits classified among different categories were contemplated as possible interrelated architectural processes.

Vigor parameters Length and Nb_IN were highly correlated, $r=0.899$ (Table 3), which is not unexpected, since a longer main axis is expected to present a higher number of internodes. In addition, both variables were also negatively correlated with d_Top above the threshold. Length, as well as IN_L, were selected as descriptors of tree vigor.

For branch quantity parameters, BbyL and BbyIN presented a correlation value of +0.887 (Table 3). Both depended on the number of branches (Table 1), describing similar aspects of the phenotype. Despite BbyL having a lower $p$-value (Table 2), BbyIN was chosen as a branch quantity descriptor because it also described the potentiality of a given node to become a branch. $\mathrm{Nb} \_\mathrm{sB}$ and $\mathrm{Nb} \_\mathrm{mB}$ were positively correlated with $\mathrm{Nb} \_\mathrm{B}$, presenting an $r>0.7$ (0.722 and 0.801, respectively) (Table 3). Therefore, the amount of short and medium shoots ( $\mathrm{Nb} \_\mathrm{sB}$ and $\mathrm{Nb} \_\mathrm{mB}$ ) might depend primarily on the total number of branches. The number of long shoots $\left(\mathrm{Nb} \_\mathrm{lB}\right)$ appeared to be more independent of the total number of branches, $r=0.397$. Thus, Nb_lB was kept with $\mathrm{Nb} \_\mathrm{B}$ as a branch quantity descriptor. Finally, B_NbAS, did not show correlation values above the 0.7 threshold with any other parameter, and so, with no reason to discard it, the B_NbAS parameter was added to the list of branch quantity descriptors.

For branch distribution parameters, both Dist_Down and Dist_Up were highly correlated with Dist_B, $r=-0.796$ and $r=0.914$, respectively (Table 3). Since Dist_B describes the overall distribution of branches along the trunk and not their concentration in a single part of the main axis, it was taken as the unique branch distribution descriptor. As it was the only branching angle parameter at this point, conferring therefore little descriptive value, Top_SO was excluded from subsequent analyses. In summary, seven parameters were selected as representative of three different categories: Length, IN_L, Nb_B BbyIN, B_NbAS, Nb_lB and Dist_B. 


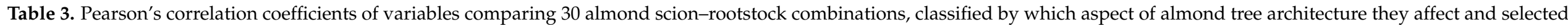
by rootstock influence. Refer to Table 1 for abbreviations.

\begin{tabular}{|c|c|c|c|c|c|c|c|c|c|c|c|c|c|c|c|c|}
\hline & & \multicolumn{4}{|c|}{ Vigor } & \multicolumn{7}{|c|}{ Branch Quantity } & \multicolumn{3}{|c|}{ Branch Distribution } & \multirow{2}{*}{$\begin{array}{c}\begin{array}{c}\text { Branch } \\
\text { Habit }\end{array} \\
\text { Top_SO } \\
\end{array}$} \\
\hline & & Nb_IN & Length & IN_L & d_Top & Nb_B & BbyIN & BbyL & B_NbAS & Nb_sB & Nb_mB & $\mathrm{Nb} \_1 \mathrm{~B}$ & Dist_B & Dist_Down & Dist_Up & \\
\hline \multirow{4}{*}{ Vigor } & $\mathrm{Nb}$ IN & 1.000 & & & & & & & & & & & & & & \\
\hline & Length & 0.899 & 1.000 & & & & & & & & & & & & & \\
\hline & IN_L & -0.306 & 0.078 & 1.000 & & & & & & & & & & & & \\
\hline & d_Top & -0.707 & -0.711 & 0.075 & 1.000 & & & & & & & & & & & \\
\hline \multirow{4}{*}{$\begin{array}{l}\text { Branch } \\
\text { quantity }\end{array}$} & $\mathrm{Nb} \_\mathrm{B}$ & 0.323 & 0.246 & -0.169 & -0.229 & 1.000 & & & & & & & & & & \\
\hline & BbyIN & -0.587 & -0.563 & 0.233 & 0.472 & 0.437 & 1.000 & & & & & & & & & \\
\hline & BbyL & -0.490 & -0.591 & -0.177 & 0.445 & 0.489 & 0.887 & 1.000 & & & & & & & & \\
\hline & B_NbAS & -0.483 & -0.485 & 0.067 & 0.501 & -0.268 & 0.215 & 0.165 & 1.000 & & & & & & & \\
\hline \multirow{3}{*}{ Branch vigor } & Nb_sB & 0.458 & 0.366 & -0.224 & -0.351 & 0.722 & 0.084 & 0.148 & -0.394 & 1.000 & & & & & & \\
\hline & $\mathrm{Nb} \_\mathrm{mB}$ & 0.257 & 0.219 & -0.161 & -0.234 & 0.801 & 0.281 & 0.361 & -0.225 & 0.359 & 1.000 & & & & & \\
\hline & $\mathrm{Nb} \_\mathrm{lB}$ & -0.214 & -0.220 & 0.122 & 0.260 & 0.397 & 0.616 & 0.547 & 0.211 & -0.155 & 0.186 & 1.000 & & & & \\
\hline \multirow{3}{*}{$\begin{array}{c}\text { Branch } \\
\text { distribution }\end{array}$} & Dist_B & -0.656 & -0.672 & 0.084 & 0.622 & -0.088 & 0.452 & 0.409 & 0.393 & -0.124 & -0.113 & 0.113 & 1.000 & & & \\
\hline & Dist_Down & 0.540 & 0.579 & -0.026 & -0.480 & -0.041 & -0.434 & -0.398 & -0.262 & 0.031 & -0.031 & -0.112 & -0.796 & 1.000 & & \\
\hline & Dist_Up & -0.596 & -0.580 & 0.140 & 0.602 & -0.174 & 0.362 & 0.308 & 0.372 & -0.210 & -0.190 & 0.128 & 0.914 & -0.584 & 1.000 & \\
\hline Branch habit & Top_SO & 0.121 & 0.088 & -0.045 & -0.034 & -0.016 & -0.010 & 0.000 & -0.072 & -0.050 & 0.035 & -0.007 & 0.022 & -0.078 & 0.030 & 1.000 \\
\hline
\end{tabular}

Parameters with an $r$ value higher than +0.7 or lower than -0.7 between members of the same category are in bold. 
Correlations between parameters belonging to different categories were also studied to identify possible interactions. The vigor parameter Length was correlated with the branch quantity traits BbyIN and B_NbAS and with the branch distribution variable Dist_B, indicating a potential interaction between the height of the main axis and these parameters. Furthermore, BbyIN was positively correlated with the branch distribution trait Dist_B (Table 3).

\subsection{Analysis of Rootstock and Cultivars of Interest}

Scion-rootstock combinations affected tree height (Length), but the effect was not consistent across the different rootstocks or scion cultivars. For example, 'Isabelona' or 'Diamar' trees grafted onto Rootpac ${ }^{\circledR} 20$, a low vigor rootstock, were taller when compared with the other rootstocks in this study, while 'Soleta' and 'Vialfas' trees on Rootpac ${ }^{\circledR}$ 20 were shorter (Table 4). Moreover, 'Isabelona' and 'Vialfas' trees grafted on 'Garnem' rootstock, a high vigor rootstock, were taller when compared with trees grafted with the other rootstocks in this study, while 'Diamar' and 'Soleta' trees on 'Garnem' rootstock were smaller. 'Lauranne' trees were smaller than the other scion cultivars across all rootstocks with the exception of Rootpac ${ }^{\circledR} R$. The trunks of 'Lauranne' trees on Rootpac ${ }^{\circledR} R$ rootstock were twice the height of 'Lauranne' trees on the other rootstocks. Internode length (IN_L) was similar across all scion/rootstock combinations, with only a few cultivars grafted onto the dwarfing rootstock 'GN-8' showing significant low IN_L values (Table 4).

Branching quantity traits were substantially affected by rootstock choice in our cultivars of interest. When grafted onto 'Garnem' rootstock, the number of branches (Nb_B) was significantly higher on 'Guara', 'Isabelona' and 'Vialfas' trees compared with trees on the dwarfing rootstocks 'GN-8' and Rootpac ${ }^{\circledR} 20$. Likewise, branching frequency, the number of branches per node (BbyIN), was less when cultivars were grafted onto Rootpac ${ }^{\circledR}$ 20 and 'GN-8'. Combinations with both Rootpac ${ }^{\circledR} 40$ and Rootpac ${ }^{\circledR} \mathrm{R}$ also produced more branches through all scion cultivars (Table 4).

There were more long shoots on scion cultivars grafted onto 'Garnem' rootstock compared with the other rootstocks (Table 4). A similar effect was detected with trees grafted onto Rootpac ${ }^{\circledR} 40$, but not as consistently across the different scion cultivars as with 'Garnem'. Cultivars grafted onto 'GN-8' and Rootpac ${ }^{\circledR} 20$ showed the opposite phenotype, with few long shoots. Despite no significant differences being observed in the number of secondary branches (B_NbAS), cultivars 'Lauranne', 'Soleta' or 'Guara' presented a higher tendency to develop second order branches (Table 4).

Only 'Diamar' and 'Soleta' displayed significant differences of Dist_B between rootstocks combinations. Otherwise, there were no consistent trends observed across the scion-rootstock combinations. (Table 4).

Table 4. Analysis of the 7 non-redundant variables in the 30 rootstock/scion combinations, comparing by rootstock choice. Data were collected from 2-year-old trees. Refer to Table 1 for abbreviations.

\begin{tabular}{|c|c|c|c|c|c|c|c|}
\hline & & 'Lauranne' & 'Guara' & 'Isabelona' & 'Diamar' & 'Soleta' & 'Vialfas' \\
\hline \multirow{5}{*}{ Length (mm) } & 'Garnem' & $353 a$ & $707 a$ & $800 \mathrm{ab}$ & $323 c$ & $357 \mathrm{~b}$ & $1190 \mathrm{a}$ \\
\hline & 'GN-8' & $223 \mathrm{a}$ & $453 \mathrm{a}$ & $443 \mathrm{~b}$ & $820 \mathrm{ab}$ & 847 a & $313 \mathrm{~d}$ \\
\hline & Rootpac ${ }^{\circledR} 20$ & 317 a & $923 \mathrm{a}$ & 1053 a & $1053 \mathrm{a}$ & $373 b$ & $380 \mathrm{~cd}$ \\
\hline & Rootpac ${ }^{\circledR} 40$ & $317 \mathrm{a}$ & $720 \mathrm{a}$ & $450 \mathrm{~b}$ & $607 \mathrm{bc}$ & $730 \mathrm{a}$ & $697 \mathrm{~b}$ \\
\hline & $\operatorname{Rootpac}^{\circledR} \mathbf{R}$ & $690 \mathrm{a}$ & 717 a & $623 \mathrm{ab}$ & $687 \mathrm{~b}$ & $597 \mathrm{ab}$ & $653 \mathrm{bc}$ \\
\hline \multirow{5}{*}{ IN_L (mm) } & 'Garnem' & $19.0 \mathrm{a}$ & $16.7 \mathrm{a}$ & $12.4 \mathrm{a}$ & $17.0 \mathrm{a}$ & $11.0 \mathrm{a}$ & $12.8 \mathrm{ab}$ \\
\hline & 'GN-8' & $11.0 \mathrm{~b}$ & $14.5 \mathrm{a}$ & $12.1 \mathrm{a}$ & $15.9 \mathrm{a}$ & $10.6 \mathrm{a}$ & $9.2 \mathrm{~b}$ \\
\hline & Rootpac ${ }^{\circledR} 20$ & $18.8 \mathrm{a}$ & $18.5 \mathrm{a}$ & $11.0 \mathrm{a}$ & $17.6 \mathrm{a}$ & $13.1 \mathrm{a}$ & $15.1 \mathrm{a}$ \\
\hline & Rootpac ${ }^{\circledR} 40$ & $16.2 \mathrm{a}$ & $14.8 \mathrm{a}$ & $12.2 \mathrm{a}$ & $15.0 \mathrm{a}$ & $12.7 \mathrm{a}$ & $12.3 \mathrm{ab}$ \\
\hline & $\operatorname{Rootpac}^{\circledR} \mathbf{R}$ & $16.7 \mathrm{a}$ & $15.8 \mathrm{a}$ & $11.3 \mathrm{a}$ & $14.0 \mathrm{a}$ & $13.9 \mathrm{a}$ & $11.9 \mathrm{ab}$ \\
\hline
\end{tabular}


Table 4. Cont

\begin{tabular}{|c|c|c|c|c|c|c|c|}
\hline & & 'Lauranne' & 'Guara' & 'Isabelona' & 'Diamar' & 'Soleta' & 'Vialfas' \\
\hline \multirow{5}{*}{ Nb_B } & 'Garnem' & $9.0 \mathrm{ab}$ & $15.3 \mathrm{a}$ & $22.3 \mathrm{a}$ & $8.7 \mathrm{ab}$ & $14.7 \mathrm{a}$ & $18.0 \mathrm{a}$ \\
\hline & 'GN-8' & $4.0 \mathrm{~b}$ & $3.3 \mathrm{~b}$ & $8.0 \mathrm{~b}$ & $5.7 \mathrm{~b}$ & $10.3 \mathrm{a}$ & $8.7 \mathrm{bc}$ \\
\hline & Rootpac $^{\circledR} 20$ & $5.3 \mathrm{ab}$ & $2.7 \mathrm{~b}$ & $4.7 \mathrm{~b}$ & $2.7 \mathrm{~b}$ & $6.3 \mathrm{a}$ & $7.7 \mathrm{c}$ \\
\hline & Rootpac $^{\circledR} 40$ & $12.0 \mathrm{a}$ & $8.7 \mathrm{ab}$ & $8.0 \mathrm{~b}$ & $7.0 \mathrm{ab}$ & $12.0 \mathrm{a}$ & $16.7 \mathrm{ab}$ \\
\hline & Rootpac ${ }^{\circledR} \mathbf{R}$ & $11.3 \mathrm{a}$ & $12.0 \mathrm{ab}$ & $13.0 \mathrm{ab}$ & $15.0 \mathrm{a}$ & $15.3 \mathrm{a}$ & $11.7 \mathrm{abc}$ \\
\hline \multirow{5}{*}{ BbyIN } & 'Garnem' & $0.481 \mathrm{ab}$ & $0.382 \mathrm{a}$ & $0.359 \mathrm{a}$ & $0.452 \mathrm{a}$ & $0.456 \mathrm{a}$ & $0.193 \mathrm{a}$ \\
\hline & 'GN-8’ & $0.199 \mathrm{~b}$ & $0.191 \mathrm{a}$ & $0.292 \mathrm{a}$ & 0.107 c & $0.130 \mathrm{~b}$ & $0.242 \mathrm{a}$ \\
\hline & Rootpac $^{\circledR} 20$ & $0.331 \mathrm{ab}$ & $0.070 \mathrm{a}$ & $0.048 \mathrm{a}$ & $0.043 c$ & $0.232 \mathrm{ab}$ & $0.295 \mathrm{a}$ \\
\hline & Rootpac $^{\circledR} 40$ & $0.608 \mathrm{a}$ & $0.247 \mathrm{a}$ & $0.288 \mathrm{a}$ & $0.183 \mathrm{bc}$ & $0.209 \mathrm{ab}$ & $0.294 \mathrm{a}$ \\
\hline & Rootpac ${ }^{\circledR} \mathbf{R}$ & $0.365 \mathrm{ab}$ & $0.268 \mathrm{a}$ & $0.232 \mathrm{a}$ & $0.303 \mathrm{ab}$ & $0.362 \mathrm{ab}$ & $0.211 \mathrm{a}$ \\
\hline \multirow{5}{*}{$\mathbf{N b \_ 1 B}$} & 'Garnem' & $5.3 \mathrm{ab}$ & $4.7 \mathrm{a}$ & $6.3 \mathrm{a}$ & $7.7 \mathrm{a}$ & $6.3 \mathrm{a}$ & $4.3 \mathrm{a}$ \\
\hline & 'GN-8' & $3.0 \mathrm{~b}$ & $2.3 \mathrm{a}$ & $1.7 \mathrm{a}$ & $3.3 \mathrm{~b}$ & $4.0 \mathrm{ab}$ & $2.7 \mathrm{ab}$ \\
\hline & Rootpac $^{\circledR} 20$ & $3.3 \mathrm{ab}$ & $1.0 \mathrm{a}$ & $1.3 \mathrm{a}$ & $0.7 \mathrm{~b}$ & $1.7 \mathrm{~b}$ & $3.0 \mathrm{ab}$ \\
\hline & Rootpac $^{\circledR} 40$ & $7.0 \mathrm{a}$ & $3.3 \mathrm{a}$ & $2.7 \mathrm{a}$ & $1.7 \mathrm{~b}$ & $3.7 \mathrm{ab}$ & $3.7 \mathrm{a}$ \\
\hline & Rootpac $^{\circledR} \mathbf{R}$ & $4.7 \mathrm{ab}$ & $4.7 \mathrm{a}$ & $1.7 \mathrm{a}$ & $2.7 \mathrm{~b}$ & $4.0 \mathrm{ab}$ & $0.7 \mathrm{~b}$ \\
\hline \multirow{5}{*}{ B_NbAS } & 'Garnem' & $5.2 \mathrm{a}$ & $2.7 \mathrm{a}$ & $0.5 \mathrm{a}$ & $1.3 \mathrm{a}$ & $2.8 \mathrm{a}$ & $0.4 \mathrm{a}$ \\
\hline & 'GN-8' & $7.1 \mathrm{a}$ & $1.3 \mathrm{a}$ & $0.5 \mathrm{a}$ & $0.1 \mathrm{a}$ & $0.9 \mathrm{a}$ & $2.4 \mathrm{a}$ \\
\hline & Rootpac $^{\circledR} 20$ & $3.5 \mathrm{a}$ & $1.0 \mathrm{a}$ & $0.0 \mathrm{a}$ & $0.3 \mathrm{a}$ & $1.6 \mathrm{a}$ & $0.2 \mathrm{a}$ \\
\hline & Rootpac $^{\circledR} 40$ & $1.2 \mathrm{a}$ & $0.5 \mathrm{a}$ & $0.8 \mathrm{a}$ & $0.0 \mathrm{a}$ & $1.7 \mathrm{a}$ & $0.1 \mathrm{a}$ \\
\hline & $\operatorname{Rootpac}^{\circledR} \mathbf{R}$ & $2.2 \mathrm{a}$ & $0.7 \mathrm{a}$ & $0.3 \mathrm{a}$ & $0.0 \mathrm{a}$ & $2.2 \mathrm{a}$ & $0.1 \mathrm{a}$ \\
\hline \multirow{5}{*}{ Dist_B } & 'Garnem' & $0.58 \mathrm{a}$ & $0.61 \mathrm{a}$ & $0.53 \mathrm{a}$ & $0.69 \mathrm{a}$ & $0.58 \mathrm{ab}$ & $0.46 \mathrm{a}$ \\
\hline & 'GN-8' & $0.64 \mathrm{a}$ & $0.60 \mathrm{a}$ & $0.48 \mathrm{a}$ & $0.22 \mathrm{~b}$ & $0.37 \mathrm{~b}$ & $0.72 \mathrm{a}$ \\
\hline & Rootpac ${ }^{\circledR} 20$ & $0.69 \mathrm{a}$ & $0.59 \mathrm{a}$ & $0.39 \mathrm{a}$ & $0.35 \mathrm{~b}$ & $0.79 \mathrm{a}$ & $0.74 \mathrm{a}$ \\
\hline & Rootpac $^{\circledR} 40$ & $0.59 \mathrm{a}$ & $0.40 \mathrm{a}$ & $0.52 \mathrm{a}$ & $0.44 \mathrm{~b}$ & $0.49 \mathrm{~b}$ & $0.47 \mathrm{a}$ \\
\hline & Rootpac $^{\circledR} \mathbf{R}$ & $0.63 \mathrm{a}$ & $0.50 \mathrm{a}$ & $0.51 \mathrm{a}$ & $0.44 \mathrm{~b}$ & $0.57 \mathrm{ab}$ & $0.47 \mathrm{a}$ \\
\hline
\end{tabular}

Assessed with Tukey's test. Values within columns followed by the same letter were not significantly different $(p<0.05)$.

\subsection{Principal Component Analysis of Rootstock/Scion Combinations}

Once the representative parameters were defined, a principal component analysis (PCA) was carried out in order to observe if rootstock/scion combinations grouped together significantly. These analyses showed that $62.5 \%$ of the variability could be explained by the first two components (Dim1 and Dim2), while the other components explained a maximum of around $10 \%$ of the variability. Thus, only these first two components were taken into consideration.

No clear clusters of samples were observed with the same rootstocks in the PCA since there was a clear effect of the scion genotype. However, most of the combinations with low vigor rootstocks Rootpac ${ }^{\circledR} 20$ and 'GN-8' were located together below the $X$ axis (Figure 2A). Meanwhile, combinations with 'Garnem' were positioned above the remaining rootstock combinations in the PCA. Rootpac ${ }^{\circledR} \mathrm{R}$ and Rootpac ${ }^{\circledR} 40$ rootstock combinations were scattered through the plot between these two groups. Cultivars did not sort in a noteworthy way, even though a certain separation could be recognized between combinations with 'Lauranne' and the rest of cultivars, while 'Isabelona' was in the opposite extreme of the grouped cultivars (Figure 2B). Length and branch quantity parameters have opposing influence in the components, being the cause behind the differential distribution of rootstock combinations (Figure 2C). 
A

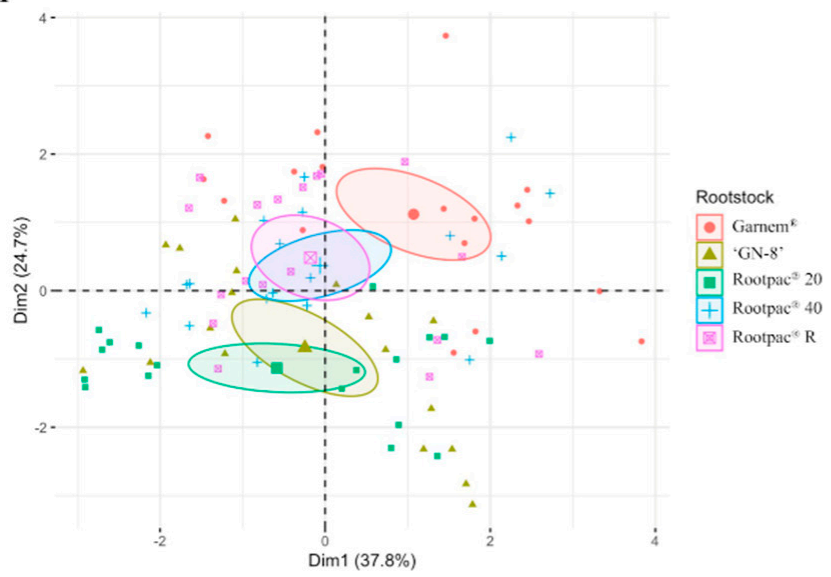

B

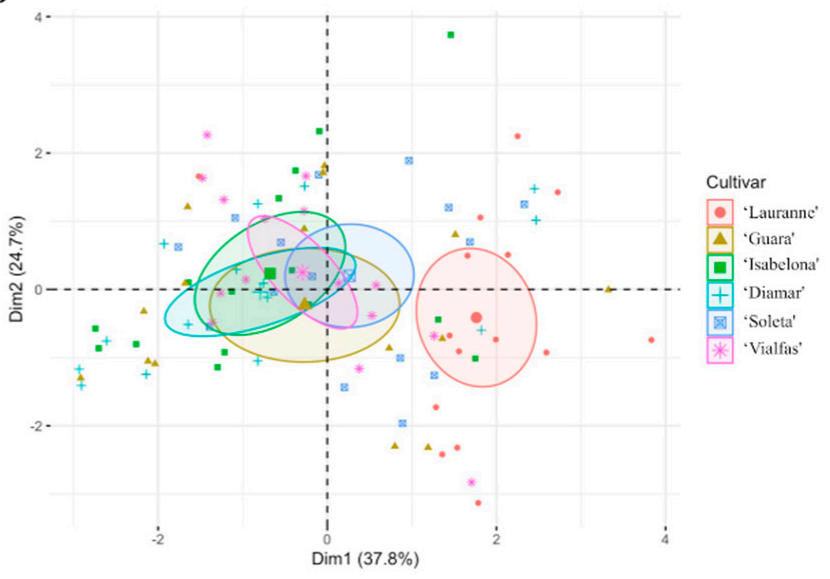

$\mathrm{C}$

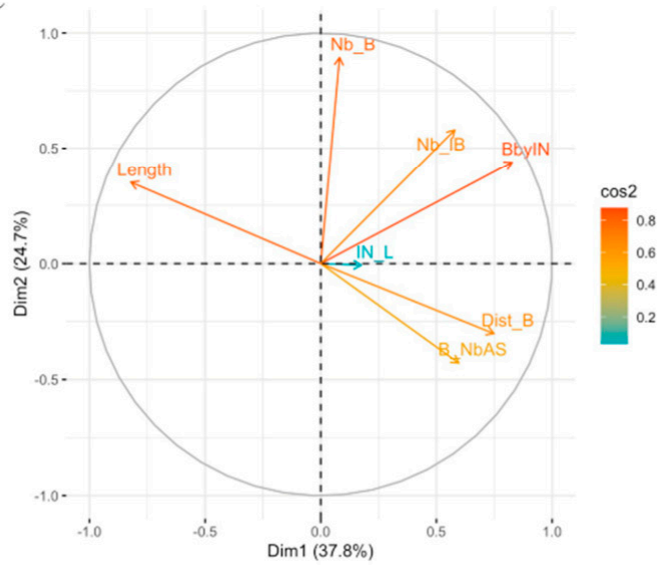

Figure 2. Principal component analysis (PCA) of seven non-redundant variables of 30 almond scion-rootstock combinations. (A) Distribution of scion-rootstock combinations classified by rootstock choice as a categorical variable with the first two components (Dim1 and Dim2), with concentration ellipses for each rootstock; (B) Distribution of scion-rootstock combinations classified by cultivar choice as a categorical variable with the first two components (Dim1 and Dim2), with concentration ellipses for each cultivar; (C) Distribution of the seven non-redundant variables with the first two components (Dim1 and Dim2). Contribution of each parameter to the components is colored from blue to red. Data were collected from 2-year-old trees. Refer to Table 1 for abbreviations.

\section{Discussion}

Combinations of five rootstocks and six scion varieties were compared in this study to identify a set of representative parameters of tree architecture influenced by rootstock choice. In the first instance, 24 parameters comprising 4 trait categories (Table 1) were sorted by how their variability was affected by rootstock/scion interaction (Table 2). Then, a Pearson's correlation test was performed for the 15 remaining parameters to identify highly correlated parameters from the same category and non-redundant variables. Correlations between parameters from different categories were also analyzed without eliminating parameters (Table 3). Only seven variables were selected after this step, and we studied how the scion-rootstock combinations affected these seven parameters and how different almond cultivars were affected by the rootstock (Table 4). Finally, these seven variables were submitted to a principal component analysis (PCA) to observe differential distributions of scion-rootstock combinations (Figure 2).

The seven parameters selected represented only three of the trait categories. Two of the parameters, Length and IN_L, belong to the category vigor. Branch quantity was represented by four different parameters Nb_B, B_NbAS. Nb_lB and BbyIN. Finally, Dist_B acts as unique representative of the branch distribution category. Practically no influence of 
the rootstock/scion interaction was detected in the branching angle category. It is of interest that the parameter IN_L and similar variables to $\mathrm{Nb}$ _B and $\mathrm{B} \_\mathrm{Nb} A S$ were found to be relevant descriptors of apple tree architecture when selected by their genetic variability [29].

A shared trend was observed in the parameters influenced by rootstock genotype, with the majority of traits involved in processes related to the control of branching. It was observed that scion-rootstock combinations were primarily distributed differentially as a function of two opposing traits (Figure 2C). The Length parameter presented a negative value for the Dim1 axis, while all branch quantity (Nb_B, BbyIN, B_NbAS, Nb_lB) parameters had positive values in the Dim1 axis. Moreover, Length was negatively correlated with BbyIN and B_NbAS (Table 3).

Apical meristem maintenance and branching control are driven by the apical dominance exerted by the apex. Apical dominance refers to the suppression of axillary bud outgrowth during and/or after extension of the parent shoot, reducing the number of sylleptic and/or proleptic shoots, respectively. Gradziel [31] has described this feature to classify primary and secondary branching patterns in almond. Apical dominance is controlled by the terminal apical meristem on the parent shoot and by the apical meristems of subordinate axillary shoots [32-34]. Auxin is regarded as the main regulator of apical dominance, while other factors and hormones have been described as participating in branching regulation [35-45]. Specifically, strigolactones (SLs) are a crucial regulator of plant architecture $[46,47]$. Application of SL analogs has been proven able to reduce branching in tree species such as olive (Olea europaea) [48].

Depending on the strength of apical dominance present, we can observe opposing phenotypes as described by Gradziel [31]. If apical dominance is strong, due to the cultivar or the rootstock effect or both, dormancy is imposed, affecting branch quantity parameters and producing low BbyIN, Nb_B and B_NbAS values, while the apical meristem would continue its growth resulting in high Length values. In contrast, with weak apical dominance, the repression of axillary buds is reduced, and more branches will develop, described by high values in branch quantity parameters. Sylleptic shoots are generally formed in the lower portion of the parent shoot, while proleptic shoots are mainly formed from subterminal buds, immediately below the shoot apex, which is consistent with the positive correlation we found between Length and Dist_Down (Table 3). While the redistribution of resources to the formation of these lateral shoots may be expected to slow the growth of the main axis, resulting in determinate growth and low Length values, this effect appears to be mainly constrained to the formation of proleptic shoots formed after a period of rest. This would explain the negative correlation we found between Length and Dist_Up. Furthermore, while the presence of medium $\left(\mathrm{Nb} \_\mathrm{mB}\right)$ and short shoots $\left(\mathrm{Nb} \_\mathrm{sB}\right)$ correlates with the total number of shoots $\left(\mathrm{Nb} \_\mathrm{B}\right)$, we found the development of long shoots $\left(\mathrm{Nb} \_\mathrm{BB}\right)$ to be more independent. This is due to the existence of few long shoots, appearing more predominantly in combination with low apical dominance but not necessarily in those with more branches (Table 4).

There is evidence from studies in peach that within the same genotype, rapid extension of the parent axis is associated with weak apical dominance and thus a high number of sylleptic axillary shoots [49]. Hence, in our study we often found more branches (Nb_B) with the more vigorous rootstocks than with the less vigorous rootstocks (Table 4). Rootpac ${ }^{\circledR}$ 20 and 'GN-8' can be described as dwarfing rootstocks, and their effects on the TCSA have been measured, proving a suppressing influence on tree vigor compared with more vigorous rootstock such as 'Garnem' and Rootpac ${ }^{\circledR} 40$ [14,50]. We did not record a strong influence of parameters related to trunk diameter, such as d_Base (Table 2). Instead we found a stronger relationship between rootstock vigor and shoot production $(\mathrm{Nb} B \mathrm{~B})$. We observed that Rootpac ${ }^{\circledR} 20$ and 'GN-8' seemed to favor apical dominance, not promoting the formation of branches and maintaining an active apical meristem. In contrast, 'Garnem' appeared to negatively affect apical dominance, forming numerous branches, including long shoots (Nb_lB) and ceasing main axis growth earlier than other rootstocks (Table 4). It is possible that this growth response is a forerunner of the strong basitonic growth 
habit evident in commercial almond orchards. A less intense but similar effect can be observed when grafted onto Rootpac ${ }^{\circledR} 40$. Rootpac ${ }^{\circledR} R$ presented a medium phenotype, with numerous branches but maintaining an active main axis (Table 4). This distribution can be observed in the PCA, where Rootpac ${ }^{\circledR} 20$ and 'GN-8' were diametrically opposed to 'Garnem', with Rootpac ${ }^{\circledR} 40$ and Rootpac ${ }^{\circledR} \mathrm{R}$ between them (Figure 2A).

Cultivars grafted onto 'GN-8' showed shorter internodes than when grafted onto more vigorous rootstocks, such as 'Garnem' or Rootpac ${ }^{\circledR} 40$ (Table 4). Internode elongation, which is mainly regulated by gibberellic acid (GA), has been described as being influenced by rootstock genotype [10,51]. However, SLs are also known to affect internode elongation independent of GA [52].

While there is ample evidence of rootstocks having a strong effect on scion tree architecture, the scion itself plays an essential part in branching regulation. Both 'Diamar' and 'Isabelona' showed a similar phenotype when grafted onto Rootpac ${ }^{\circledR} 20$, favoring apical dominance, resulting in high Length values and reduced branching, observed through all branch quantity parameters. However, once grafted onto 'Garnem', only 'Isabelona' was able to maintain an active apical meristem, while 'Diamar' ceased growth of the main axis earlier (Table 4). The cultivar 'Lauranne' presented a typical low apical dominance phenotype, developing an elevated number of both branches (BbyIN) and axillary shoots (B_NbAS) and reduced trunk length when grafted onto almost every rootstock (Table 4). Rootpac ${ }^{\circledR} \mathrm{R}$ was the only exception, promoting the formation of short horizontal branches (Nb_B) but maintaining an active main axis (Length) (Table 4).

While almond trees in commercial orchards show strong basitonic branching with strong lower limbs dominating the growth of the trunk, at the branch level, new shoot growth can predominate from basal, middle or distal sections of the parent shoot (basitonic, mesotonic and acrotonic branching, respectively) [18,24]. Dist_B, which measures branching distribution, is negatively correlated with Length and positively with BbyIN, connecting apical dominance and branch positioning (Table 3). A desirable ideotype might present the axillary shoots equally distributed through the axis, as described by Gradziel [31], presenting intermediate values for Dist_B, instead of being accumulated in a few internodes. Low apical dominance cultivar 'Lauranne' had consistent high Dist_B values (Table 4). In these combinations, the apical meristem ceases its growth early and long branches from the current season's growth form in the upper part of the trunk. 'Guara' presented a comparable phenotype to 'Lauranne', although the formation of branches from the current season's growth was more impaired by dwarfing rootstocks such as 'GN-8' and Rootpac ${ }^{\circledR} 20$. A similar effect can be observed when cultivars are grafted onto 'Garnem' (Table 4). 'Soleta' displayed significant differences of Dist_B between rootstock combinations, presenting high values when grafted onto Rootpac ${ }^{\circledR} 20$. However, this combination also presented a reduced number of long shoots (Table 4). Thus, the high Dist_B values are due to the accumulation of a few short branches in the apex, not descriptive of a lack of apical dominance.

Although they are not distributed as clearly as in the rootstocks comparison, there is a certain degree of separation between some of the cultivars in the PCA. 'Lauranne' combinations were mildly distanced from the rest of the cultivar combinations. Combinations with 'Isabelona' as the cultivar are located predominantly in the opposite extreme, yet closer to the rest of combinations (Figure 2B). Apical dominance seems to be heavily influenced by rootstock choice in some cultivars, such as 'Diamar' or 'Soleta', but not in those that present a stronger control of this feature, such as 'Lauranne'. A similar phenomenon can be observed with 'Isabelona', where the rootstock effect is more diluted (Table 4). Hence, this illustrates the importance of a correct choice of rootstock when deciding what scion cultivar should be selected for field production.

No clear influence was observed on branch angle by the rootstock choice (Table 2). This could reflect the narrow range of branching angles among the scion cultivars selected for this study. Branch angle is a complex trait regulated by several processes, where light 
perception and gravity sensing have a main relevance, which are regulated primarily at the aerial part of the plant [36,53-55].

In conclusion, seven parameters were selected as descriptors of rootstock influence in almond scion architecture. The choice of rootstock affected scion cultivar architecture, modifying both apical dominance and branch parameters. 'Garnem' and Rootpac ${ }^{\circledR} 20$ had an opposite influence on the architecture of the scion, as was observed in parameters such as Length or the number of branches $\left(\mathrm{Nb} \_\mathrm{B}\right)$, while mixed results were observed with other rootstocks. However, these processes are regulated by numerous physiological processes, and the final phenotype is not only the result of the interaction between the rootstock and the scion but also the result of rootstock and scion interaction with the environment. Cultivars with a strong or weak display of apical dominance, for example 'Lauranne' and 'Isabelona', were less affected by rootstock influence, while the other scion cultivars in this study were strongly influenced by rootstock choice. This highlights the importance of screening rootstock progeny with a number of scion genotypes, in view of the strong scion-rootstock genotype interactions. Thus, a better understanding of what is happening at the graft union and with other physiological and molecular aspects of scionrootstock interactions is needed in order to decipher the nuanced changes that determine tree architecture across a range of scion-rootstock combinations.

Author Contributions: Conceptualization, Á.M. and M.J.R.-C.; methodology, Á.M., G.T. and M.J.R.C.; formal analysis, Á.M.; investigation, Á.M. and M.J.R.-C.; data curation, Á.M.; writing-original draft preparation, Á.M., J.G. and M.J.R.-C.; writing—review and editing, G.T.; supervision, J.G. and M.J.R.-C.; project administration, M.J.R.-C.; funding acquisition, M.J.R.-C. All authors have read and agreed to the published version of the manuscript.

Funding: This research was funded by the Spanish Research State Agency (AEI), grant numbers RTI2018-094210-R-100 and FPI-INIA CPD2016-0056. Funding for G.T. was provided through the National Tree Crop Intensification in Horticulture Program (AS18000), funded by the Hort Frontiers Advanced Production Systems Fund, part of the Hort Frontiers strategic partnership initiative developed by Hort Innovation (Australia), with co-investment from Plant \& Food Research and contributions from the Australian Government.

Institutional Review Board Statement: Not applicable.

Informed Consent Statement: Not applicable.

Data Availability Statement: Not applicable.

Conflicts of Interest: The authors declare no conflict of interest. The funders had no role in the design of the study; in the collection, analyses, or interpretation of data; in the writing of the manuscript; or in the decision to publish the results.

\section{References}

1. Mudge, K.; Janick, J.; Scofield, S.; Goldschmidt, E.E. A History of Grafting. Hortic. Rev. 2009, 35, 437-493. [CrossRef]

2. Rubio-Cabetas, M.J.R.; Felipe, A.J.; Reighard, G.L. Rootstock Development. In Almonds: Botany, Production and Uses; Socias i Company, R., Gradizel, T.M., Eds.; CABI: Wallingford, UK, 2017; pp. 209-227.

3. Albacete, A.; Martínez-Andújar, C.; Martínez-Pérez, A.; Thompson, A.J.; Dodd, I.C.; Pérez-Alfocea, F. Unravelling rootstock $\times$ scion interactions to improve food security. J. Exp. Bot. 2015, 66, 2211-2226. [CrossRef] [PubMed]

4. Aloni, B.; Cohen, R.; Karni, L.; Aktas, H.; Edelstein, M. Hormonal signaling in rootstock-scion interactions. Sci. Hortic. 2010, 127, 119-126. [CrossRef]

5. Foster, T.M.; Celton, J.M.; Chagne, D.; Tustin, D.S.; Gardiner, S.E. Two quantitative trait loci, Dw1 and Dw2, are primarily responsible for rootstock-induced dwarfing in apple. Hortic. Res. 2015, 2, 9. [CrossRef]

6. Martínez-Ballesta, M.C.; Alcaraz-López, C.; Muries, B.; Mota-Cadenas, C.; Carvajal, M. Physiological aspects of rootstock-scion interactions. Sci. Hortic. 2010, 127, 112-118. [CrossRef]

7. Warschefsky, E.J.; Klein, L.L.; Frank, M.H.; Chitwood, D.H.; Londo, J.P.; von Wettberg, E.J.B.; Miller, A.J. Rootstocks: Diversity, Domestication, and Impacts on Shoot Phenotypes. Trends Plant. Sci. 2016, 21, 418-437. [CrossRef]

8. Felipe, A.J. “Felinem”, “Garnem”, and "Monegro" almond x peach hybrid rootstocks. HortScience 2009, 44, 196-197. [CrossRef]

9. Tworkoski, T.; Fazio, G. Effects of Size-Controlling Apple Rootstocks on Growth, Abscisic Acid, and Hydraulic Conductivity of Scion of Different Vigor. Int. J. Fruit Sci. 2015, 15, 369-381. [CrossRef] 
10. Tworkoski, T.; Miller, S. Rootstock effect on growth of apple scions with different growth habits. Sci. Hortic. 2007, 111, 335-343. [CrossRef]

11. Seleznyova, A.N.; Tustin, D.S.; Thorp, T.G. Apple dwarfing rootstocks and interstocks affect the type of growth units produced during the annual growth cycle: Precocious transition to flowering affects the composition and vigour of annual shoots. Ann. Bot. 2008, 101, 679-688. [CrossRef]

12. Van Hooijdonk, B.M.; Woolley, D.J.; Warrington, I.J.; Tustin, D.S. Initial alteration of scion architecture by dwarfing apple rootstocks may involve shoot-root-shoot signalling by auxin, gibberellin, and cytokinin. J. Hortic. Sci. Biotechnol. 2010, 85, 59-65. [CrossRef]

13. Balducci, F.; Capriotti, L.; Mazzoni, L.; Medori, I.; Albanesi, A.; Giovanni, B.; Giampieri, F.; Mezzetti, B.; Capocasa, F. The rootstock effects on vigor, production and fruit quality in sweet cherry (Prunus avium L.). J. Berry Res. 2019, 9, 249-265. [CrossRef]

14. Lordan, J.; Zazurca, L.; Maldonado, M.; Torguet, L.; Alegre, S.; Miarnau, X. Horticultural performance of 'Marinada' and 'Vairo' almond cultivars grown on a genetically diverse set of rootstocks. Sci. Hortic. 2019, 256, 108558. [CrossRef]

15. Hallé, F.; Oldeman, R.A.A.; Tomlinson, P.B.; Hallé, F.; Oldeman, R.A.A.; Tomlinson, P.B. Forests and Vegetation. In Tropical Trees and Forests; Springer: Berlin/Heidelberg, Germany, 1978. [CrossRef]

16. Costes, E.; Lauri, P.-E.; Regnard, J.L. Analyzing Fruit Tree Architecture: Implications for Tree Management and Fruit Production. Hort. Rev. 2006, 32, 1-61. [CrossRef]

17. Barthélémy, D.; Caraglio, Y. Plant architecture: A dynamic, multilevel and comprehensive approach to plant form, structure and ontogeny. Ann. Bot. 2007, 99, 375-407. [CrossRef]

18. Costes, E.; Crespel, L.; Denoyes, B.; Morel, P.; Demene, M.-N.; Lauri, P.-E.; Wenden, B. Bud structure, position and fate generate various branching patterns along shoots of closely related Rosaceae species: A review. Front. Plant. Sci. 2014, 5, 666. [CrossRef]

19. Hallé, F. Branching in Plants. In Branching in Nature; Centre de Physique des Houches, Fleury, V., Gouyet, J.F., Léonetti, M., Eds.; Springer: Berlin/Heidelberg, Germany, 2001; Volume 14. [CrossRef]

20. Durand, J.B.; Guédon, Y.; Caraglio, Y.; Costes, E. Analysis of the plant architecture via tree-structured statistical models: The hidden Markov tree models. New Phytol. 2005, 166, 813-825. [CrossRef] [PubMed]

21. Guédon, Y.; Barthélémy, D.; Caraglio, Y.; Costes, E. Pattern analysis in branching and axillary flowering sequences. J. Theor. Biol. 2001, 212, 481-520. [CrossRef] [PubMed]

22. Costes, E.; Guédon, Y. Modelling branching patterns on 1-year-old trunks of six apple cultivars. Ann. Bot. 2002, 89, 513-524. [CrossRef] [PubMed]

23. Seleznyova, A.N.; Thorp, T.G.; Barnett, A.M.; Costes, E. Quantitative analysis of shoot development and branching patterns in Actinidia. Ann. Bot. 2002, 89, 471-482. [CrossRef]

24. Negrón, C.; Contador, L.; Lampinen, B.D.; Metcalf, S.G.; Dejong, T.M.; Guédon, Y.; Costes, E. Systematic Analysis of Branching Patterns of Three Almond Cultivars with Different Tree Architectures. J. Am. Soc. Hortic. Sci. 2013, 138, 407-415. [CrossRef]

25. Negrón, C.; Contador, L.; Lampinen, B.D.; Metcalf, S.G.; Guédon, Y.; Costes, E.; Dejong, T.M. How different pruning severities alter shoot structure: A modelling approach in young "Nonpareil" almond trees. Funct. Plant. Biol. 2015, 42, 325-335. [CrossRef] [PubMed]

26. Negrón, C.; Contador, L.; Lampinen, B.D.; Metcalf, S.G.; Guédon, Y.; Costes, E.; Dejong, T.M. Differences in proleptic and epicormic shoot structures in relation to water deficit and growth rate in almond trees (Prunus dulcis). Ann. Bot. 2014, 113, 545-554. [CrossRef] [PubMed]

27. Migault, V.; Pallas, B.; Costes, E. Combining Genome-Wide Information with a Functional Structural Plant Model to Simulate 1-Year-Old Apple Tree Architecture. Front. Plant. Sci. 2017, 7, 2065. [CrossRef] [PubMed]

28. Segura, V.; Cilas, C.; Costes, E. Dissecting apple tree architecture into genetic, ontogenetic and environmental effects: Mixed linear modelling of repeated spatial and temporal measures. New Phytol. 2008, 178, 302-314. [CrossRef]

29. Segura, V.; Cilas, C.; Laurens, F.; Costes, E. Phenotyping progenies for complex architectural traits: A strategy for 1-year-old apple trees (Malus x domestica Borkh.). Tree Genet. Genomes 2006, 2, 140-151. [CrossRef]

30. Coupel-Ledru, A.; Pallas, B.; Delalande, M.; Boudon, F.; Carrié, E.; Martinez, S.; Regnard, J.-L.; Costes, E. Multi-scale highthroughput phenotyping of apple architectural and functional traits in orchard reveals genotypic variability under contrasted watering regimes. Hortic. Res. 2019, 6, 52. [CrossRef] [PubMed]

31. Gradziel, T.M. The utilization of wild relatives of cultivated almond and peach in modifying tree architecture for crop improvement. Acta Hortic. 2012, 948, 271-278. [CrossRef]

32. Cline, M.G. Apical dominance. Bot. Rev. 1991, 57, 318-358. [CrossRef]

33. Dun, E.A.; Ferguson, B.J.; Beveridge, C.A. Apical dominance and shoot branching. Divergent opinions or divergent mechanisms? Plant. Physiol. 2006, 142, 812-819. [CrossRef] [PubMed]

34. Hollender, C.A.; Dardick, C. Molecular basis of angiosperm tree architecture. New Phytol. 2015, 206, 541-556. [CrossRef]

35. Barbier, F.F.; Dun, E.A.; Kerr, S.C.; Chabikwa, T.G.; Beveridge, C.A. An Update on the Signals Controlling Shoot Branching. Trends Plant. Sci. 2019, 24, 220-236. [CrossRef]

36. Casal, J.J. Shade Avoidance. Arab. B. 2012, 10, e0157. [CrossRef]

37. Dun, E.A.; de Saint Germain, A.; Rameau, C.; Beveridge, C.A. Antagonistic action of strigolactone and cytokinin in bud outgrowth control. Plant. Physiol. 2012, 158, 487-498. [CrossRef] 
38. Mason, M.G.; Ross, J.J.; Babst, B.A.; Wienclaw, B.N.; Beveridge, C.A. Sugar demand, not auxin, is the initial regulator of apical dominance. Proc. Natl. Acad. Sci. USA 2014, 111, 6092-6097. [CrossRef]

39. Pereira-Netto, A.B.; Roessner, U.; Fujioka, S.; Bacic, A.; Asami, T.; Yoshida, S.; Clouse, S.D. Shooting control by brassinosteroids: Metabolomic analysis and effect of brassinazole on Malus prunifolia, the Marubakaido apple rootstock. Tree Physiol. 2009, 29, 607-620. [CrossRef]

40. Rameau, C.; Bertheloot, J.; Leduc, N.; Andrieu, B.; Foucher, F.; Sakr, S. Multiple pathways regulate shoot branching. Front. Plant. Sci. 2015, 5, 741. [CrossRef]

41. Kieber, J.J.; Schaller, G.E. Cytokinin signaling in plant development. Development 2018, 145, dev149344. [CrossRef] [PubMed]

42. Waldie, T.; McCulloch, H.; Leyser, O. Strigolactones and the control of plant development: Lessons from shoot branching. Plant. J. 2014, 79, 607-622. [CrossRef]

43. Wang, B.; Smith, S.M.; Li, J. Genetic Regulation of Shoot Architecture. Annu. Rev. Plant. Biol. 2018, 69, 437-468. [CrossRef] [PubMed]

44. De Jong, M.; Ongaro, V.; Ljung, K. Auxin and Strigolactone Signaling are Required for Modulation of Arabidopsis Shoot Branching by Nitrogen Supply. Plant. Physiol. 2014, 166, 384-395. [CrossRef]

45. Xu, J.; Zha, M.; Li, Y.; Ding, Y.; Chen, L.; Ding, C.; Wang, S. The interaction between nitrogen availability and auxin, cytokinin, and strigolactone in the control of shoot branching in rice (Oryza sativa L.). Plant. Cell Rep. 2015, 34, 1647-1662. [CrossRef]

46. Napoli, C. Highly branched phenotype of the petunia dad1-1 mutant is reversed by grafting. Plant. Physiol. 1996, 111, 27-37. [CrossRef]

47. Simons, J.L.; Napoli, C.A.; Janssen, B.J.; Plummer, K.M.; Snowden, K.C. Analysis of the DECREASED APICAL DOMINANCE genes of petunia in the control of axillary branching. Plant. Physiol. 2007, 143, 697-706. [CrossRef]

48. Chesterfield, R.J.; Vickers, C.E.; Beveridge, C.A. Translation of Strigolactones from Plant Hormone to Agriculture: Achievements, Future Perspectives, and Challenges. Trends Plant. Sci. 2020, 25, 1087-1106. [CrossRef] [PubMed]

49. Génard, M.; Pagès, L.; Kervella, K. Relationship between sylleptic branching and components of parent shoot development in the peach tree. Ann. Bot. 1994, 74, 465-470. [CrossRef]

50. Ben Yahmed, J.; Ghrab, M.; Ben Mimoun, M. Eco-physiological evaluation of different scion-rootstock combinations of almond grown in Mediterranean conditions. Fruits 2016, 71, 185-193. [CrossRef]

51. Hearn, D.J. Perennial Growth, Form and Architecture of Angiosperm Trees. In Comparative and Evolutionary Genomics of Angiosperm Trees; Groover, A., Cronk, Q., Eds.; Springer: Cham, Switzerland, 2016; Volume 21, pp. 179-204. [CrossRef]

52. De Saint Germain, A.; Ligerot, Y.; Dun, E.A.; Pillot, J.-P.; Ross, J.J.; Beveridge, C.A.; Rameau, C. Strigolactones Stimulate Internode Elongation Independently of Gibberellins. Plant. Physiol. 2013, 163, 1012-1025. [CrossRef] [PubMed]

53. Finlayson, S.A.; Krishnareddy, S.R.; Kebrom, T.H.; Casal, J.J. Phytochrome regulation of branching in arabidopsis. Plant. Physiol. 2010, 152, 1914-1927. [CrossRef] [PubMed]

54. Kolesnikov, Y.S.; Kretynin, S.V.; Volotovsky, I.D.; Kordyum, E.L.; Ruelland, E.; Kravets, V.S. Molecular mechanisms of gravity perception and signal transduction in plants. Protoplasma 2016, 253, 1005. [CrossRef]

55. Schüler, O.; Hemmersbach, R.; Böhmer, M. A Bird's-Eye View of Molecular Changes in Plant Gravitropism Using Omics Techniques. Front. Plant. Sci. 2015, 6, 1176. [CrossRef] [PubMed] 